Historic, Archive Document

Do not assume content reflects current

scientific knowledge, policies, or practices. 



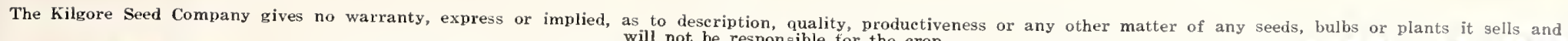

If interested in flowers and bulbs, send for Kilgore's special "FLOWER AND BULB PLANTING GUIOE FOR THE 1930 के

Available September 1, 1930.

Important_Order from this folder until you receive Kilgore's 1931 catalog about Deeember-1990

\section{SEED BEANS}

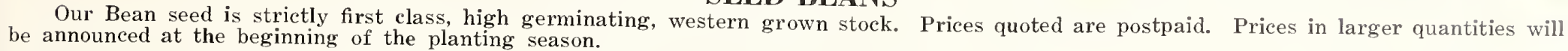

DWARF or BUSH BEANS. Plant $3 \mathrm{pks}$. to a bu. of seed per acre. GREEN PODDED BUSH BEANS. Packet Pint Quart

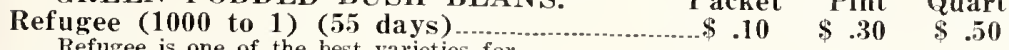
Refugee is one of the best varieties for
planting, because it is extremely hardy, fall planting, because it is ex'remely hardy,
lesisting frost better than all other varieties. In addition, it is a very heavy pro-

ducer.

Bountiful (46 days)

Giant Stringless Green Pod (45 days)

Kilgore's Stringless Refugee (50 days)

Kilgore's Stringless Long Round Green Pod (4: days)

Burpee's Stringless Green Pod (45 days). Sold out until Nov. 1st

Black Valentine (43 days)

Early Speckled Red Valentine (46 days)

Tennessee Green Pod (48 days)

$\begin{array}{lll}.10 & .45 & .80 \\ .10 & .45 & .80 \\ .10 & .45 & .80 \\ & & \\ .10 & .45 & .80 \\ & & \\ .10 & .45 & .80 \\ .10 & .35 & .65 \\ .10 & .35 & .65 \\ .10 & .35 & .65\end{array}$

Longfellow (45 days)

WAX PODDED BUSH BEANS.

Kilgore's Stringless Wax (46 days)

Kilgore's Golden Bountiful Wax (45 days)

Davis Wax (48 days)

Hodson Wax (55 days)

POLE BEANS. Plant 1 peck of seed per acre.

Kentucky Wonder (Old Homestead) (60 days) .... .10

Kilgore's Cornfield (58 days)

McCaslan (60 days) Pack

$\begin{array}{rrr}.10 & \text { Pint } & \text { Quart } \\ .35 & .65\end{array}$

Fordhook Bush Lima (65 days) 1 bushel of seed per acre. Henderson's Bush Lima (60 days) ...........................

BUTTER BEANS. Plant 1 bushel of seed per acre.

Old Florida Pole (75 days) …….

Old Florida Bush (65 days)

$\begin{array}{ll}.10 & .3 \\ .10 & .35 \\ .10 & .4 \\ .10 & .4 \\ & \\ .10 & .3 \\ .10 & .4 \\ .10 & .4 \\ \text { per acre. } \\ .10 \\ .10 & .4 \\ \text { acre. } & .4 \\ .10 & .4 \\ .10 & .40\end{array}$

.65

.65

.85

45

$35 \quad .65$

$40 \quad .70$

.80

.70

.70

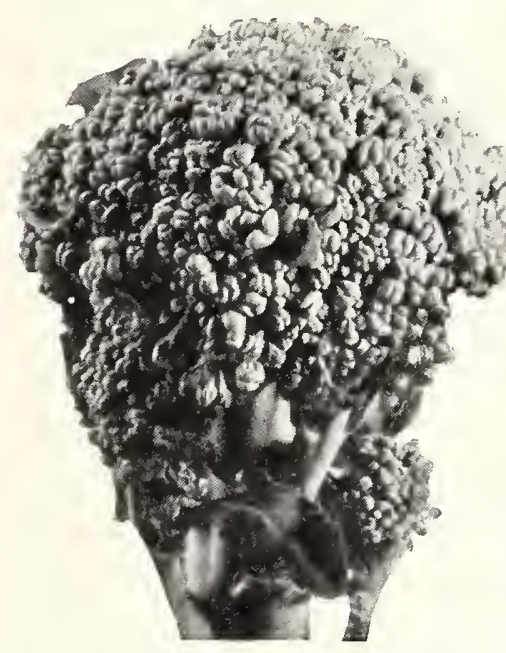

KILGORE'S BRED-RITE ITALIAN GREEN SPROUTING BROCCOLI
BROCCOLI. Sow $1 / 4$ to $1 / 2$ pound of seed in seed-bed to plant an acre. Kilgore's Bred-Rite Italian Green Sprouting or Christmas Calabrese

(115 days)

This is the true Calabrese type which is a tremendous yielder. It is the only type that buyers want and it always brings highest prices on the markets. This popular new vegetable has taken Northern markets by storm, and we consider it one of the most profitable fall and winter crops for the South.

Plkt. 25e; 1/2 oz. 65e; oz. \$1.25; 1/4 lb. $\$ 1.00 ; \mathrm{Ib} . \$ 15.00 ; 10$ lbs. $\$ 140.00$. BRUSSELS SPROUTS. Sow $1 / 4$ pound of seed in seed-bed to plant an acre.

Improved Long Island (90 days)..Pkt. $10 \mathrm{c} ; 02.25 \mathrm{c} ; 1 / 4$ 1b. $75 \mathrm{c} ; 1 \mathrm{lb} . \$ 2.50$ BEETS. Plant 6 pounds of seed per acre.

Kilgore's Early Blood-Red Market (68 Pkt. 1/4 lb. Lb. $10 \mathrm{lbs}, 25 \mathrm{lbs}$. days) $\$ .10 \$ .45 \quad \$ 1.50 \quad \$ 14.00 \quad \$ 31.25$

Very early, uniform in shape, size and color. Very attractive in appearance, free of fibrous roots or strings, making it a money-maker on any market.

Early Wonder (73 days)

Crosby's Egyptian ( 75 days)

Detroit Dark Red (76 days)

Early Blood Turnip (75 days)

Stock Beet, Long Red Giant ( 80 days)

Sugar Beet, Klein Wanzleben ( 80 days)

Swiss Chard (Spinach Beet)

$\begin{array}{rrrrr}.10 & .40 & 1.25 & 11.50 & 25.00 \\ .10 & .35 & 1.00 & 9.00 & 20.00 \\ .10 & .35 & 1.00 & 9.00 & 20.00 \\ .10 & .35 & 1.00 & 9.00 & 20.00 \\ .10 & .20 & .60 & 5.00 & 11.25 \\ .10 & .25 & .65 & 5.50 & 12.50 \\ .10 & .30 & .90 & 8.00 & 18.75\end{array}$

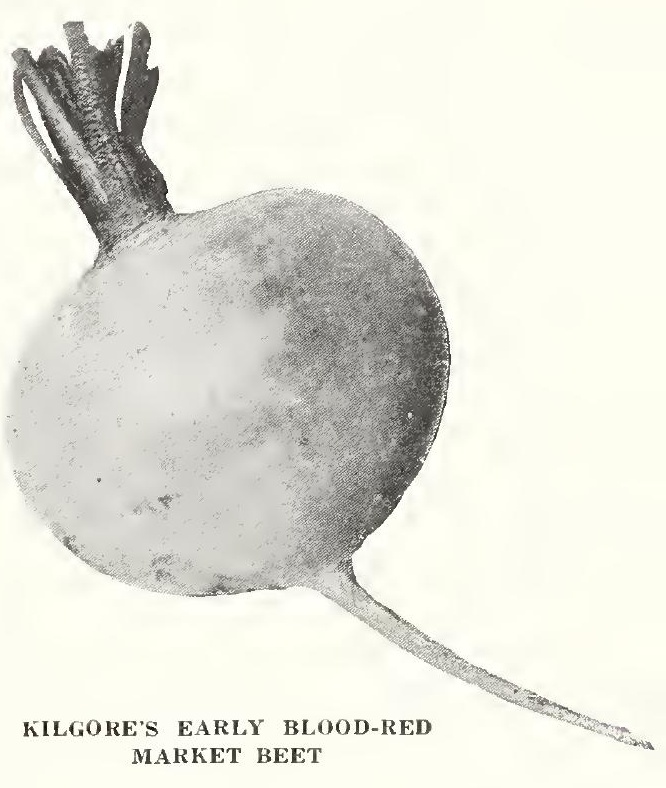

CABBAGE. Sow 6 ounces of seed in seed-bed to plant an acre. Plant 12 ounces of seed per acre in field.

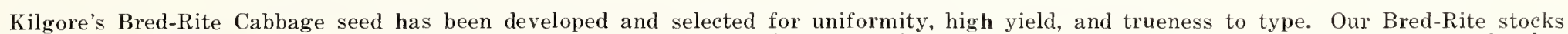

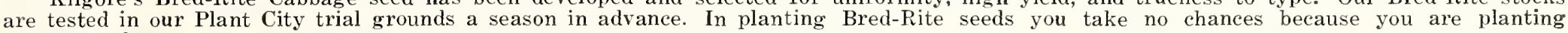
proven seed.

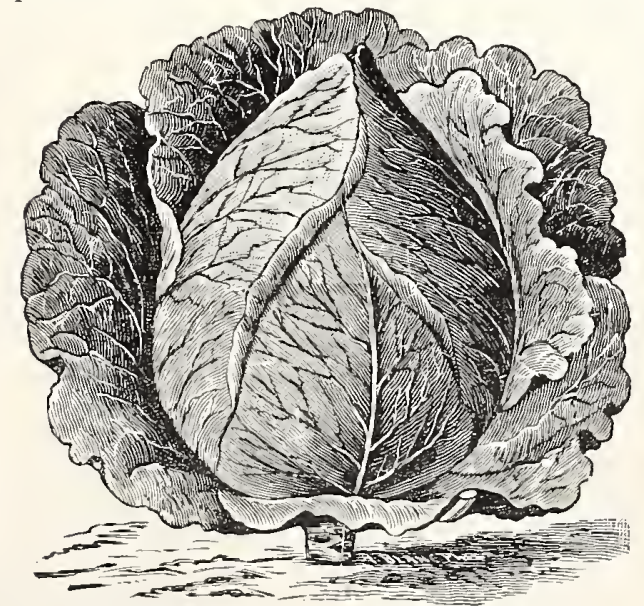

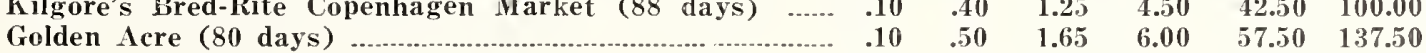
America (85 days)

Our stocks of selected cabbage seed are of high germination and compare favorably with stocks generally offered by other seedsmen at higher prices.

Selected Early Jersey Wakefield (82 days)

Selected Charleston Wakefield (88 days)

Selected Copenhagen Market (90 days)

Glory of Enkhuizen (95 days)

Allhead Early (95 days)

Savoy Cabbage, American Drumhead (100 days)

Stein's Early Flat Dutch (100 days)

Mammoth Red Rock (110 days)

Pkt. Oz. 1/4 lb. Lb. 10 lbs. $25 \mathrm{lbs}$. CHINESE CABBAGE.

KILGORE'S BRED-RITE CHARLESTON WAKEFIELD CABBAGE

Pe-Tsai

.10
.10
.10
.10
.10
.10
.10
.10

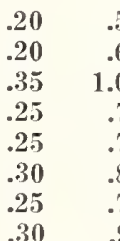

$.55 \quad 1.75$

2.00

15.00

17.50

$1.00 \quad 3.50$

$.70 \quad 2.25$

2.25

.70
85
7.00

$.70 \quad 2.25$

2.25
3.00

20.00

20.00

27.50

20.00

27.50 


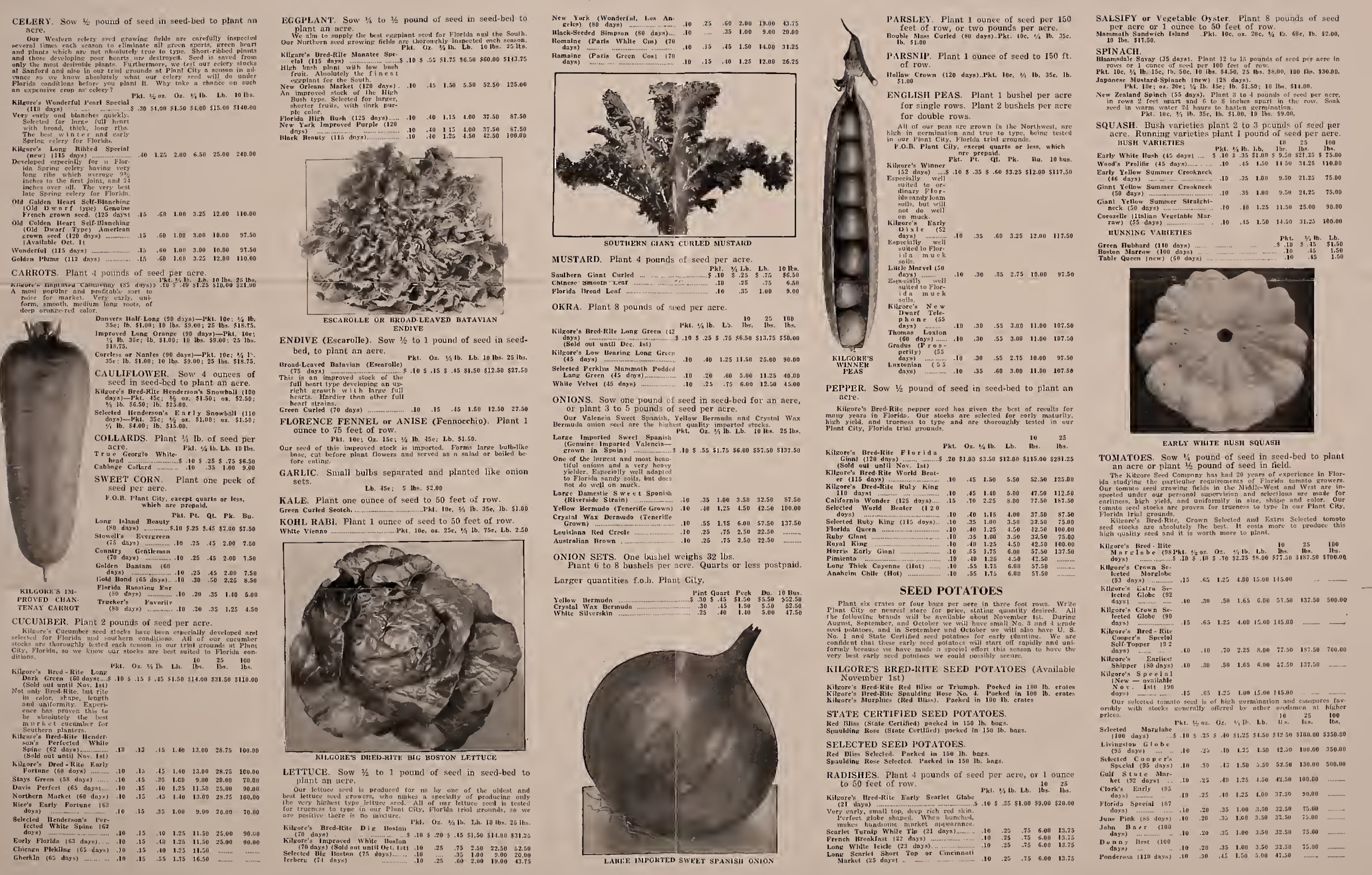




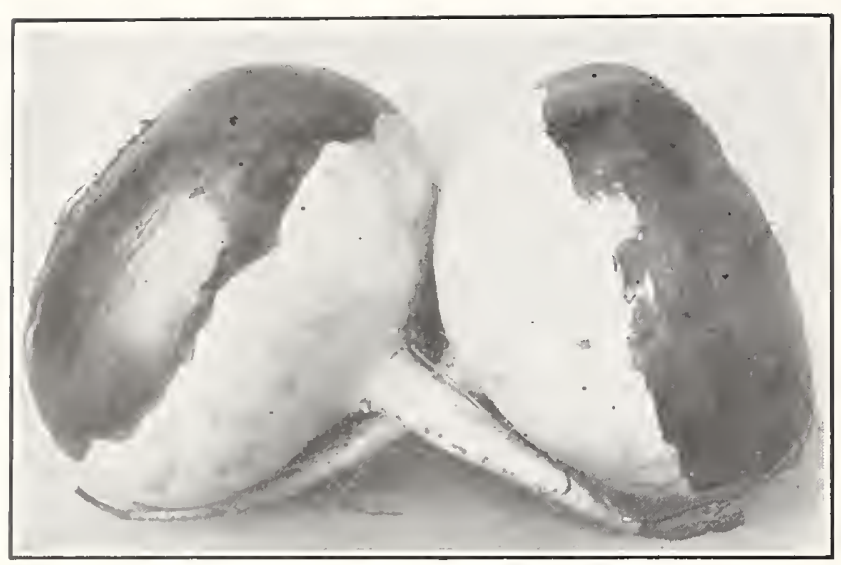

K1LGORES EARLY F1,ORIDA TURNIP

TURNIISS AND RUTABAG $\Lambda$ S. Plant 2 to 3 pounds of

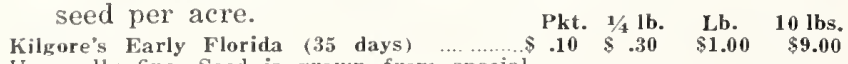

Unusually fine. Seed is grown from specia

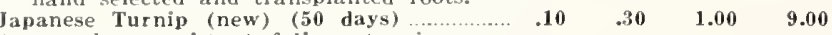

Japanese Turnip (new) (5iagre turnip, espe-

cially valuable for turnip greens.

Purple Top White Globe (50 days).

Early White Egg (45 days)

Early White Flat Dutch (42 days)

White Gloie (44 days)

Rutabaga, American Improved (90 days)
GRASS AND FARM CROP SEEDS

All prices quoted are F.O.B. Plant City, except $10 \mathrm{lb}$. lots or less, which are prepaid. KILGORE'S FLORIDA LAWN AND GOLF COUNE GRASS MIXTE. - Will quickly proat the rate of $1 / 2$ pound to 100 square feet or 200 pounds per acre. $1 / 4$ lb. $20 \mathrm{c} ; 1 / 2$ lb. $30 \mathrm{c} ; 1 \mathrm{~b} .50 \mathrm{c} ; 10$ lbs, $\$ 4.75 ; 25$ lbs. $\$ 10.00 ; 100$ lbs. $\$ 35.00 ; 200$ lbs. $\$ 65.00,500$ Ibs. $\$ 150.00$.

BERMUDA GRASS.-The South's most dependable and permanent grass. Plant 25 lbs. per acre for pasture. Plant 100 pounds per acre or $1 / 4$
pound per 100 square feet for lawns or golf

$1 / 4$ lb. 20c; lb. 55c; 10 lbs. $\$ 5.00 ; 25$ Its. \$11.25; 100 lbs. $\$ 40.00 ; 500$ lbs. $\$ 187.50$

CARPET GRASS.-- Especially well adapted to Florida soil and climatic conditions. Grows under relatively poor soil ferility conditions, and is 100 hardy. A very good pasture grass. Plant lawn. per acre or 14 lb. per 100 square feet for for pasture.

$1 / 1$ lb, 20c; lb. $45 \mathrm{c} ; 10$ lbs. $\$ 4.00 ; 25$ lbs, $\$ 8.75$; 100 lbs. $\$ 25.00 ; 500$ lis. $\$ 100.00$

ITALIAN RYE GRASS (Florida's Blue Grass.) A desirable, quick-growing fall and winter grass giving way as soon as warm weather comes on, Plant 50 pounds per acre for grazing or for hay. Plant 200 pounds per acre or one-half pound per 100 square feet for lawns and golf courses.

$1 / 2$ lb. $15 \mathrm{c} ; 1 \mathrm{~b} .25 \mathrm{c} ; 10$ lbs. $\$ 2.00 ; 25$ lbs. $\$ 3.50$; 100 lts. $\$ 10.00 ; 500$ lis. $\$ 45.00 ; 1000$ lbs. $\$ 85.00$; 5000 lbs. $\$ 400.00$ RED TOP (Herd's Grass).-Especially valuable
for fall and winter lawns and golf courses. It is
Also a splendid pasture grass. Goes down in summer weather in Florida.

Plant 15 to 20 pounds per acre for pasture or for hay. Plant 50 pounds per acre or $1 / 4 \mathrm{lb}$. per $1 / 4$ lb. $20 \mathrm{c} ; 1$ b. 50c; 10 lbs. $\$ 4.50 ; 25$ iss. $\$ 10.00$ 100 lts. $\$ 35.00$

RYE.-Rye is perhaps the most valuable and leading fall and winter forage crop for Florida. amount of puzing and broadeast 1 bushel per acre.

Abruzzi $\quad$ Qt. $\$$ Pk. Bu. $10 \mathrm{Bu}$.

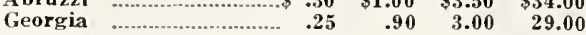
OATS.-A bushel weigks 32 pounds. Plant 2 or more bushels per acre. Fulghum (110 days) $\begin{gathered}\text { Qt. } \\ \text { Pk. }\end{gathered}$ Bu. 10 Bu. Texas Rust Proof (130 0000

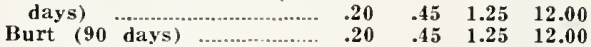

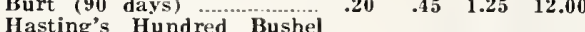
$\begin{array}{lllllll}\text { Hasting's Hundred Bushel } & .20 & .50 & 1.40 & 13.25\end{array}$

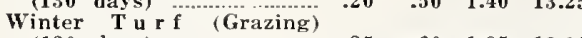

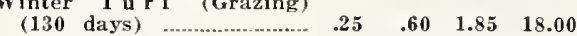
DWARF ESSEX RAPE.-A valuable fall and winter green-forage crop for poultry, cattle, hogs or a 8 , Pict

10 lbs. $\$ 2.25$

SUNFLOWER, MAMMOTH RUSSIAY-An invaluable crop for the voultryman. Inexpensive to grow, matures quickly, and yields an abundance of poultry feed. Plant 6 pounds par acre in rows $3 \mathrm{ft}$. apart, and 1 foot between hills in the row.

Thin to one plant per hill. $1 / 2$ lb. 15 c; 10. $25 \mathrm{c} ; 10$ lbs. $\$ 2.25 ; 25$ lbs. $\$ 4.00$ : 100 lbs. $\$ 12.50$.

\section{QUALITY}

Kilgore's Bred-Rite Seeds are the result of 20 years careful study, experimentation and testing in an endeavor to develop special stocks of seed to meet the requirements of Florida and Southern truck growers.

This high quality seed results in increased production, more uniform pack, better quality, and higher prices than can be secured from most other stocks of seed.

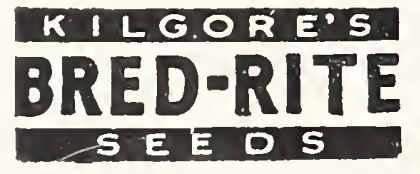

TRADE-MARK

Why plant less than the best?

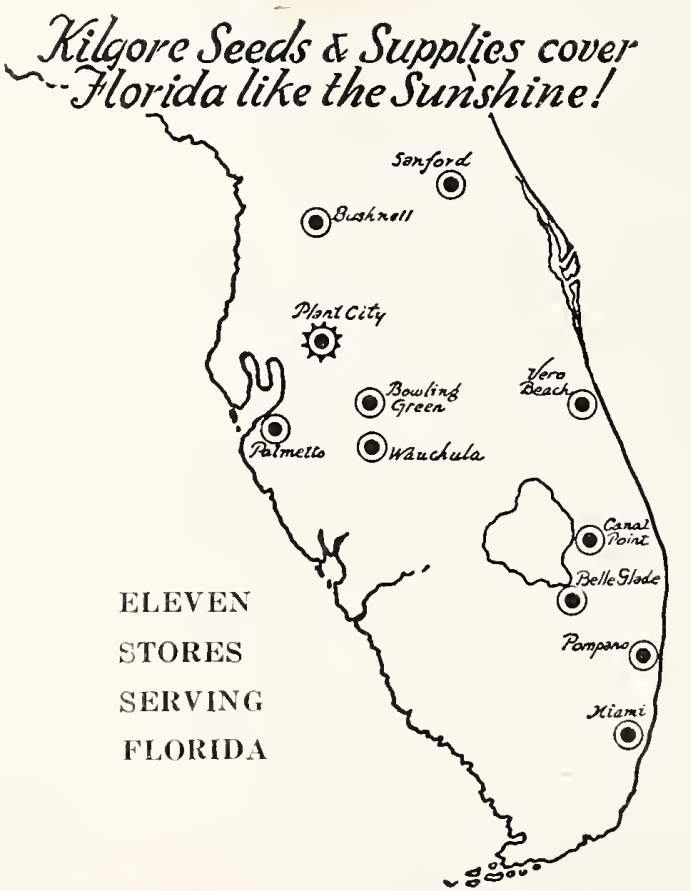

\section{SERVICE}

In addition to an efficient and well organized mail order department at Plant City, Florida, The Kilgore Seed Company has established stores at strategic points in central and south Florida for the convenience of its thousands of Florida customers. These stores carry full stocks of seeds and supplies for the truck grower.

Everything for the Florida Grower.

THE KILGORE SEED COMPANY Plant City, Florida
IMPORTANT

Return Postage Guaranteed

THE KILGORE

SEED COMPANY

Plant City, Florida

It isn't what you pay for the seed, it is what it $w$ ill produce that counts.
KILGORE'S BRED-RITE SEEDS FOR FALL 1930

Order from this folder until you receive Kilgore's 1931 Catalog about December 1st.
Sec. $435 \frac{1}{2}$ P. L. \& R.

U. S. POSTAGE

\section{PAID}

Permit No. 1

Plant City, Fla.

Kilgore's seeds are not only priced rite, but they will produce rite, bec a us they are Bred-Rite. 